\title{
AC 2010-1252: SPATIAL SKILL ASSESSMENT AS A PREDICTOR OF STUDENT PERFORMANCE IN A FIRST YEAR DESIGN FOUNDATIONS COURSE
}

Stan Guidera, Bowling Green State University 


\title{
Spatial skill assessment as a predictor of student performance in a first year design foundations course
}

\begin{abstract}
This paper documents the results of an investigation of the relationship between spatial visualization abilities and academic performance for first year architecture, construction, and interior design students, all of which were enrolled in an introductory design course their first semester of post-secondary education. The study also looked at the influence of factors such as the student's previous art, CAD and drafting coursework at the high school level. At the beginning of the semester the Purdue Visualization of Rotations (ROT) test was given to the students enrolled in an introductory design course which had development of design visualization and representation skills as a primary course outcome. This paper reports the results of the data analysis and subsequent conclusions and provides recommendations for using this instrument as an assessment tool in order to determine if supplemental activities are required for students in similar design foundations-type courses.
\end{abstract}

\section{Introduction}

The ability to conceptualize three-dimensional space and form is fundamental to development of design skills. Research first recognized spatial skills as a separate aspect of general intelligence in the early $20^{\text {th }}$ century ${ }^{1}$. Spatial visualization is described as "the mental manipulation of spatial information to determine how a given spatial configuration would appear if portions of that configuration were to be rotated, folded, repositioned, or otherwise transformed." ${ }^{2}$ and is considered central to the design process as it provides a bridge between design and design representation. ${ }^{3}$ The development or improvement of 3-D spatial visualization skills is often cited as one of the major goals of engineering design graphics education ${ }^{3}$ but is particularly important in the field of architecture and engineering, ${ }^{4}$ where expertise is associated with the development of three dimensional "knowledge acquisition processes" and specialized skills for making inferences about the 3dimensional nature of the building from 2-dimensional geometry ${ }^{5}$. The importance of spatial visualization skills was further emphasized by the perceptual psychologist Rudolf Arnheim's position that "thinking, then, is mostly visual thinking." ${ }^{6}$

Esparragoza ${ }^{7}$ proposed that spatial visualization abilities are to a large extent analogous to any other human trait, stating that "there are some people who can run faster than others the same as there are some people who have the ability of processing visual information better than others" and that "engineers, designers and scientists should have visual abilities above average people to be creative and resourceful professional." 7 Therefore, spatial ability has been found to be a predictor for academic performance for engineering as well as related disciplines. ${ }^{8}$

However, research has found that performance among students with lower levels of spatial skill can be remediated with additional supplemental activities such as multi-view sketching and modeling exercises. ${ }^{8,9}$ Similarly, Esparragoza ${ }^{7}$ proposed that "training to help the students to develop and enhance their visualization skills can be done by means of problems and exercises in the orthographic projection and axonometric drawings topics." He cited the role of two multimedia tutorials, the Visual Reasoning Tutorial (VRT) and the Orthographic Projection Tutor 
(OPT), in improving skills in a freshman engineering class. The VRT consists of fourteen missing view problems and the OPT consists of 32 sets of problems each of them with more than one exercise involving orthographic projections concepts. In many academic areas introductory design courses are used to develop fundamental design and visualization skills in order to establish a foundation on which more advanced coursework is based. Anecdotal as well as empirical evidence suggest that spatial visualization skills play a critical role in the student success in these courses. Therefore, the ability for educators to identify students with lower levels of visualization skills early in such courses would provide an opportunity to supplement coursework with activities specifically designed to enhance spatial and visualization skills.

As a result, a study was developed to investigate ways to determine if a spatial visualization assessment instrument could be effectively used to identify students with lower levels of skills. The purpose of the study was to investigate the extent to which this specific visual skills assessment tool could be used to predict academic performance in basic or foundation-level class. The study also investigated the relationship between prior coursework in manual drafting, computer aided drafting (CAD), and general art and performance on the Purdue Visualization Tests. The study utilized The Purdue Visualization Test, which has been widely used in research related to multiple disciplines and is considered to be a spatial ability test "whose results are least likely to be complicated by analytical processing." 8 The tests were given to the students enrolled in an interdisciplinary introductory design course offered by the Department of Architecture at Bowling Green State University. Development of design visualization and representation skills was a primary course outcome and objective.

The Purdue Visualization test, also known as the Purdue Visualization of Rotations Test, consists of three sections, each of which has 12 multiple-choice questions. These are referred to in this paper as "folding," "views," and "rotations." For the folding section participants are provided a series of 12 tasks each consisting of a set of five isometric views of 3-D objects which are somewhat similar in geometry. These are accompanied by a 2-D view of the unfolded surfaces of one of the five objects. Participants are asked to identify which of the five options corresponds to the unfolded surface (Figure 1).

In the views section, participants are provided a series of 12 tasks each consisting of an isometric view of a 3-D object depicted as positioned in the center of the volume of an isometric wireframe cube. For each task, the wire-frame isometric includes a mark at one of the cubes corners. The participant is asked to mentally orient their view towards the object from that corner indicated by the marker and select the correct corresponding view from the five alternative views of the object that were provided (Figure 2).

For the rotations section, participants are provided two isometric views of a 3-D object, the first shows the object in what is to be considered a reference orientation (pre-rotation) and a second which depicts the same object after it has been rotated (post-rotation). An isometric of a second object is accompanied by a set of five views of possible rotations of that object. Participants are asked to select the view which depicts the orientation of the object if it had undergone the same rotation process (or processes) as those of the reference object (Figure 3).

\section{Study Methodology}


The study population was drawn from students from four sections of the design foundations course. The course enrollment consisted of architecture, construction, and interior design students, most of which were enrolled in their first semester of post-secondary education. The course also included students who were undecided or were from other disciplines although these students numbered less than 10 in total. There were four sections of the class, each with 20 students. Three instructors were assigned to the course, one of which taught two sections and two taught one section each. All four sections followed the same syllabus for assignments and class schedule.

The data were collected using a paper survey which was used to collect demographic information. Students were asked to identify the following:

1. academic major

2. Number of manual drafting classes completed prior to start of the current semester;

3. Number of CAD (Computer Aided Drafting) classes completed prior to start of the current semester;

4. Number of art (non-technical or computer-based) classes completed prior to start of the current semester

Item 1 was used to analyze the data to determine if there were any relationships between performance on the visualization assessment and academic major. As this was nominal data, analysis was limited to non-parametric tests. Items 2 through 4 were used to collect data that would be used to determine the relationship between prior coursework and performance on the visualization assessment. These were classified as ordinal data, with categories of "none" (0), "one" (1), "two" (2), and "three or more" (3).

After completing the initial survey, the participants were asked to complete the three sections of the Purdue Visualization Test. As with the survey, the PVT sections were administered using paper copies. The tests were not individually timed, although approximately 30 minutes were allocated to the three sections combined.

There were eight different variables associated with data related to the responses to the three sections of the Purdue Visualization Test. The data was entered for each participant as a percentage of correct responses with a separate score for "folding," "views," and "rotations." The mean of the three categories was then calculated to provide a combined score. Therefore, there were four PVT scores that were scaled variables used in analysis. Bi-variate correlation tests were used for analysis of ordinal- ordinal and ordinal-scale variables. Non-parametric analysis of these variables used Spearman's rho. Additionally, the three individual test scores and the combined score were re-calculated into quartile ratings consisting of $0-24 \%, 25-49 \%$, $50-74 \%$, and $75-100 \%$, which resulted in a new set of ordinal variables. This was done in order to assess the extent to which a more broad-based grouping would provide a more effective assessment process. This would also allow for additional analysis using non-parametric tests (chi-square) that are appropriate for nominal to nominal and nominal ordinal data. The final grade in the class was then entered as a variable called "grade." This was structured as an ordinal variable consisting of A (4), B (3), C (2), D (1), and F (0). 


\section{Results}

Sixtyeight $(74 \%)$ of the students enrolled at the beginning of the class chose to participate in the study. Of these, two students dropped the class reducing the number of participants included in the study to 65 . The majority of the students were architecture majors. Students classified as "other" represented only $7.7 \%$ of the respondents. The breakdown of the participants by academic major is documented in Table 1.

Table 1: MAJOR

\begin{tabular}{llllll}
\hline & & Frequency & Percent & $\begin{array}{l}\text { Valid } \\
\text { Percent }\end{array}$ & $\begin{array}{l}\text { Cumulative } \\
\text { Percent }\end{array}$ \\
\hline Valid & ARCH & 26 & 40.0 & 40.0 & 40.0 \\
\hline CM & 22 & 33.8 & 33.8 & 73.8 \\
\hline ID & 12 & 18.5 & 18.5 & 92.3 \\
\hline Other & 5 & 7.7 & 7.7 & 100.0 \\
\hline Total & 65 & 100.0 & 100.0 & \\
\hline
\end{tabular}

In order to provide context for the analysis of the results of the Purdue Visualization Tests, chisquare tests were used to investigate relationships between participants' academic major and final grade, as well as between academic major and the participants' prior course experience.

Only 51 of the participants provided the additional demographic data related to prior coursework. The statistical analysis software excluded the participants that did not respond. The tests yielded no significant relationship between major and final grade when adjusted for nominal data (i.e. major). Regarding prior coursework, a significant relationship was found between academic major and prior art experience. None was found between CAD and drafting coursework and academic major.

The official grades given to the 65 remaining students ranged from A through $F$ with a mean grade of $3.35(\mathrm{~B}+)$. This was higher than anticipated, particularly since the instructors were varied across the sections. The scores on the sections of the Purdue Visualization Tests were more varied. All three sections ranged from a low of .08 (8\% or 1 correct) to 1.00 (100\% or 12 correct). As a result, the mean score for each of the three sections was similar with .6068 $(60.7 \%)$ for the folding section, .6129 (61.3\%), for the views section, and .5463 (54.6\%) for the rotations section. The mean of the combined score (mean of the three sections) was .5463 $(54.6 \%)$. These results are documented in Table 2.

Table 2: Folding

\begin{tabular}{llllll}
\hline & $\mathrm{N}$ & Minimum & Maximum & Mean & Std. Deviation \\
\hline $\begin{array}{l}\text { Folding } \\
\text { Score }\end{array}$ & 65 & .08 & 1.00 & .6068 & .26049 \\
\hline $\begin{array}{l}\text { Views } \\
\text { Score }\end{array}$ & 65 & .08 & 1.00 & .6129 & .25297 \\
\hline $\begin{array}{l}\text { Rotation } \\
\text { Score }\end{array}$ & 65 & .08 & 1.00 & .5463 & .21834 \\
\hline $\begin{array}{l}\text { COMBSC } \\
\text { OR }\end{array}$ & 65 & .17 & 1.00 & .5887 & .19257 \\
\hline $\begin{array}{l}\text { Valid N } \\
\text { (listwise) }\end{array}$ & 65 & & & & \\
\hline
\end{tabular}


The results of the statistical analysis were mixed. Analysis using bi-variate correlation yielded no statistical significance between any of the prior course work categories and any of the PVT section scores or the PVT combined score. Similar results were found when replacing the scale PVT variables with the quartile variables. However, statistically significant correlations were found between the final grade and the folding section scores $(\rho=.045)$, the views section scores $(\varrho=.022)$, and the combined grade scores $(\rho=.023)$. These results are documented in Table 3 . Nonparametric tests using Spearman's rho found significant relationships between final grade and the folding section scores $(\rho=.037)$, the views section scores $(\rho=.013)$, and the combined grade scores $(\rho=.024)$. These results are documented in Table 4 . When replacing the scale PVT variables with the quartile variables, bi-variate correlation analysis yielded statistically significant correlations between the final grade and the folding section scores $(\varrho=.010)$ and the views section scores $(\rho=.014)$, but the quartile variable for combined scores was not significant.

Results of analysis of the tests scores using non-parametric tests (chi-square tests) to a large extent supported the outcomes of the correlation analysis. When considering the final grade data relative to the quartile rankings for each PVT section as well as the quartile rankings for the combined scores, the chi-square tests found statistically significant results for final grade to quartile ranked folding (.014), final grade to quartile ranked views (.025), and final grade to quartile combined score (.002).

Table 3: Correlations

\begin{tabular}{|c|c|c|c|c|c|c|c|c|c|}
\hline & & Prior Art & $\begin{array}{l}\text { Prior } \\
\text { CAD }\end{array}$ & $\begin{array}{l}\text { Prior } \\
\text { Drafting }\end{array}$ & $\begin{array}{l}\text { Folding } \\
\text { Score }\end{array}$ & $\begin{array}{l}\text { Views } \\
\text { Score }\end{array}$ & $\begin{array}{l}\text { Rotation } \\
\text { Score }\end{array}$ & Grade & $\begin{array}{l}\text { Combined } \\
\text { score }\end{array}$ \\
\hline \multirow[t]{3}{*}{ Prior Art } & $\begin{array}{l}\text { Pearson } \\
\text { Correlation }\end{array}$ & 1 & -.398 & -.331 & .078 & -.209 & -.228 & -.017 & -.137 \\
\hline & $\begin{array}{l}\text { Sig. (2- } \\
\text { tailed) }\end{array}$ & . & .004 & .018 & .588 & .141 & .107 & .908 & .339 \\
\hline & $\mathrm{N}$ & 51 & 51 & 51 & 51 & 51 & 51 & 50 & 51 \\
\hline \multirow[t]{3}{*}{$\begin{array}{l}\text { Prior } \\
\text { CAD } \\
\end{array}$} & $\begin{array}{l}\text { Pearson } \\
\text { Correlation }\end{array}$ & -.398 & 1 & .647 & -.147 & .274 & .226 & -.103 & .133 \\
\hline & $\begin{array}{l}\text { Sig. (2- } \\
\text { tailed) }\end{array}$ & .004 & . & .000 & .302 & .051 & .111 & .477 & .351 \\
\hline & $\mathrm{N}$ & 51 & 51 & 51 & 51 & 51 & 51 & 50 & 51 \\
\hline \multirow[t]{3}{*}{$\begin{array}{l}\text { Prior } \\
\text { Drafting }\end{array}$} & $\begin{array}{l}\text { Pearson } \\
\text { Correlation } \\
\end{array}$ & -.331 & .647 & 1 & .063 & .134 & .201 & -.087 & .158 \\
\hline & $\begin{array}{l}\text { Sig. (2- } \\
\text { tailed) }\end{array}$ & .018 & .000 & . & .661 & .348 & .158 & .548 & .270 \\
\hline & $\mathrm{N}$ & 51 & 51 & 51 & 51 & 51 & 51 & 50 & 51 \\
\hline \multirow[t]{3}{*}{$\begin{array}{l}\text { Folding } \\
\text { Score }\end{array}$} & $\begin{array}{l}\text { Pearson } \\
\text { Correlation }\end{array}$ & .078 & -.147 & .063 & 1 & .326 & .525 & .230 & .792 \\
\hline & $\begin{array}{l}\text { Sig. (2- } \\
\text { tailed) }\end{array}$ & .588 & .302 & .661 & . & .008 & .000 & .066 & .000 \\
\hline & $\mathrm{N}$ & 51 & 51 & 51 & 66 & 66 & 66 & 65 & 66 \\
\hline \multirow[t]{3}{*}{$\begin{array}{l}\text { Views } \\
\text { Score }\end{array}$} & $\begin{array}{l}\text { Pearson } \\
\text { Correlation } \\
\end{array}$ & -.209 & .274 & .134 & .326 & 1 & .451 & .119 & .760 \\
\hline & $\begin{array}{l}\text { Sig. (2- } \\
\text { tailed) }\end{array}$ & .141 & .051 & .348 & .008 & . & .000 & .346 & .000 \\
\hline & $\mathrm{N}$ & 51 & 51 & 51 & 66 & 66 & 66 & 65 & 66 \\
\hline \multirow[t]{2}{*}{$\begin{array}{l}\text { Rotation } \\
\text { Score }\end{array}$} & $\begin{array}{l}\text { Pearson } \\
\text { Correlation }\end{array}$ & -.228 & .226 & .201 & .525 & .451 & 1 & .258 & .813 \\
\hline & Sig. (2- & .107 & .111 & .158 & .000 & .000 & & .038 & .000 \\
\hline
\end{tabular}




\begin{tabular}{|c|c|c|c|c|c|c|c|c|c|}
\hline & tailed) & & & & & & & & \\
\hline & $\mathrm{N}$ & 51 & 51 & 51 & 66 & 66 & 66 & 65 & 66 \\
\hline \multirow[t]{3}{*}{ Grade } & $\begin{array}{l}\text { Pearson } \\
\text { Correlation }\end{array}$ & -.017 & -.103 & -.087 & .230 & .119 & .258 & 1 & .253 \\
\hline & $\begin{array}{l}\text { Sig. (2- } \\
\text { tailed) }\end{array}$ & .908 & .477 & .548 & .066 & .346 & .038 & . & .042 \\
\hline & $\mathrm{N}$ & 50 & 50 & 50 & 65 & 65 & 65 & 65 & 65 \\
\hline \multirow[t]{3}{*}{$\begin{array}{l}\text { Combined } \\
\text { score }\end{array}$} & $\begin{array}{l}\text { Pearson } \\
\text { Correlation }\end{array}$ & -.137 & .133 & .158 & .792 & .760 & .813 & .253 & 1 \\
\hline & $\begin{array}{l}\text { Sig. (2- } \\
\text { tailed) }\end{array}$ & .339 & .351 & .270 & .000 & .000 & .000 & .042 & . \\
\hline & $\mathrm{N}$ & 51 & 51 & 51 & 66 & 66 & 66 & 65 & 66 \\
\hline
\end{tabular}

Table Non-parametric tests using Spearman's rho

\begin{tabular}{|c|c|c|c|c|c|c|}
\hline & & $\begin{array}{l}\text { Folding } \\
\text { Score }\end{array}$ & $\begin{array}{l}\text { Views } \\
\text { Score }\end{array}$ & $\begin{array}{l}\text { Rotation } \\
\text { Score }\end{array}$ & $\begin{array}{l}\text { Combined } \\
\text { score }\end{array}$ & Grade \\
\hline Folding & Correlation & 1.000 & .323 & .502 & .794 & .259 \\
\hline \multirow[t]{2}{*}{ Score } & Coefficient & & & & & \\
\hline & $\begin{array}{l}\text { Sig. }(2- \\
\text { tailed })\end{array}$ & . & .008 & .000 & .000 & $.037 *$ \\
\hline Views & Correlation & .323 & 1.000 & .464 & .738 & .116 \\
\hline \multirow[t]{2}{*}{ Score } & Coefficient & & & & & \\
\hline & $\begin{array}{l}\text { Sig. (2- } \\
\text { tailed) }\end{array}$ & .008 & . & .000 & .000 & .357 \\
\hline Rotation & Correlation & .502 & .464 & 1.000 & .795 & .307 \\
\hline \multirow[t]{2}{*}{ Score } & Coefficient & & & & & \\
\hline & $\begin{array}{l}\text { Sig. (2- } \\
\text { tailed) }\end{array}$ & .000 & .000 & . & .000 & $.013 *$ \\
\hline \multirow[t]{2}{*}{ Grade } & $\begin{array}{l}\text { Correlation } \\
\text { Coefficient }\end{array}$ & .259 & .116 & .307 & .279 & 1.000 \\
\hline & $\begin{array}{l}\text { Sig. }(2- \\
\text { tailed })\end{array}$ & .037 & .357 & .013 & .024 & . \\
\hline \multirow[t]{2}{*}{$\begin{array}{l}\text { Combined } \\
\text { score }\end{array}$} & $\begin{array}{l}\text { Correlation } \\
\text { Coefficient }\end{array}$ & .794 & .738 & .795 & 1.000 & .279 \\
\hline & $\begin{array}{l}\text { Sig. }(2- \\
\text { tailed })\end{array}$ & .000 & .000 & .000 & . & $.024 *$ \\
\hline
\end{tabular}

\section{Conclusions and recommendations}

The purpose of the study was to investigate the extent to which this specific visual skills assessment tool could be used to predict academic performance in a basic or foundation-level class. The study also investigated the relationship between prior coursework in manual drafting, computer aided drafting (CAD), and general art and performance on the Purdue Visualization Tests. Conclusions drawn from the results of the data and data analysis must acknowledge the distribution of final grades was higher than would be expected in a more typical bell curve distribution in which the mean of the final grades would be nearer an average of 2.0 to 2.5 on a five-point scale of $0(\mathrm{~F})$ to $4.0(\mathrm{~A})$ as opposed to the mean of the final grade for the participants in this study which was 3.35 on a scale of 0 to 4.0. Additionally, while there were 65 participants 
in this study, that number did not provide enough responses in some categories to yield conclusive evidence of statistical significance when analyzing the data using non-parametric tests, particularly in terms of relationship between major and test scores.

The analysis of the participants' academic major relative to final grade suggests that there was no relationship between these variables. This would be anticipated since the disciplines in the course are at least to some extent related. Similarly, with the exception of art, the lack of a significant relationship between prior course work and academic major would be anticipated as it would be logical to assume many students going into architecture, interior design, and construction would take courses in drafting and CAD. Further analysis would be required to investigate the relationship between prior art courses and academic major but that is beyond the scope and purpose of this study.

In response to the study's stated purpose and accompanying research questions, when considering the influence of prior coursework, the data in this study did not find any relationship between prior coursework in drafting, computer aided drafting, or art and performance on any of the three individual sections of the PVT or in the score generated by the mean of the three sections. The reasons for this are unclear as it would be expected that students with extensive prior coursework in a visualization-related field would have produced higher scores. This may be attributable to the limited population size as well as the lack of reporting of prior course work data by several participants. These results suggest that this is an area for further study.

When considering the relationship of test scores to final grade the data suggest that the PVT appears to provide a reliable predictor of student performance. More specifically, the consistency of the significant relationships between final grade and PVT scores using both parametric and non-parametric tests suggested that there was reasonable reliability that the PVT could be used to predict academic performance in this class. It should be noted that, although there were multiple sections and instructors, the study population was limited to a specific course and semester. Therefore, the extent to which these results could be extrapolated to other courses and academic areas is inherently limited. However, the results demonstrate that spatial and visualization skill assessment tools have the potential to provide design educators with insight into the skill sets of their students early in design foundation courses such as that used in this study. Given that research has suggested that supplemental course activities and tutorials enhance visualization skills ${ }^{6,8}$, insight into student skill sets would enable faculty to target students needing additional assistance. Further research into alternative assessment tools, as well as alternative methods of administering the tests such as digitally based tests or tests administered online, could assist in determining if there are alternative tests and delivery methods that would prove to be more effective in predicting student performance.

\section{Bibliography}

1 Kelly, T. (1928). Crossroads in the mind of man. Stanford, CA: Stanford Press

2 Salthouse, T. A., \& Mitchell, D. R. D. (1990). Effects of age and naturally occurring experience on spatial visualization performance. Developmental Psychology, 26, (p. 845-854). 
3 Bertoline, G., Wiebe, E., Miller, C., and Nasman, L. (1995). Engineering Graphics Communication. Chicago: Irwin Press

4 Sorby, S. (1999). Developing 3-D Spatial Visualization Skills. Engineering Design Graphics Journal,Vol 63, No 2 .

5 Gobert, J. (1999). Expertise in the Comprehension of Architectural Plans (Knowledge Acquistion and Inference Making)". Visual and Spatial Reasoning in Design (JS Gero \&B Tversky, Ed.)

6 Arnheim, R. (1986). A plea for visual thinking. New Essays on the Psychology of Art. University of California Press, Berkeley,CA, (p. 135-152).

7 Esparragoza, I.,(2004), Enhancing visualization skills in freshman engineering students. Proceedings of the 59th Annual Meeting and Conference of the ASEE Engineering Design Graphics Division,21-23 November, 2004 Williamsburg, VA.

8 Potter, C. and Van der Merwe, E. (2001). Spatial ability, visual imagery and academic performance in engineering graphics.

9 Potter, C. and Van der Merwe, E. (1993). Academic Performance in Engineering. South African Journal of Higher Education, Vol. 7, No. 1, (p. 33-46).

10 Bodner, G., and Guay, R. (1997). The Purdue Visualization of Rotations Test. The Chemical Educator. Vol. 2,No. 4.

1
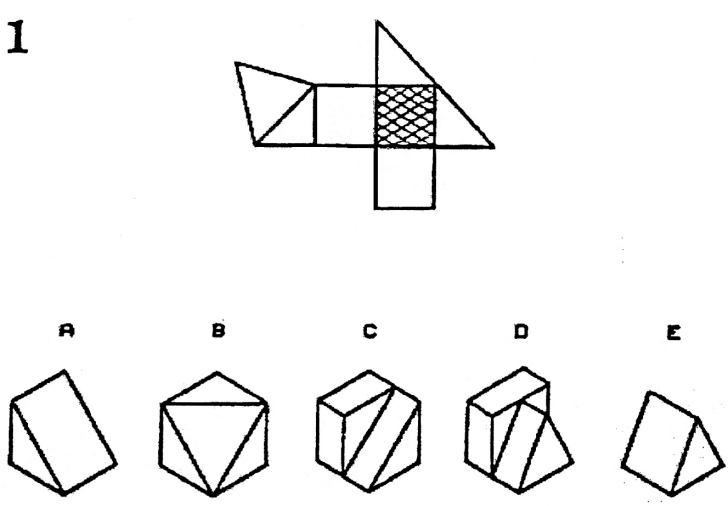

Fig. D.3. PSVT:Developments, Item 1

Figure 1. Folding Test Example 


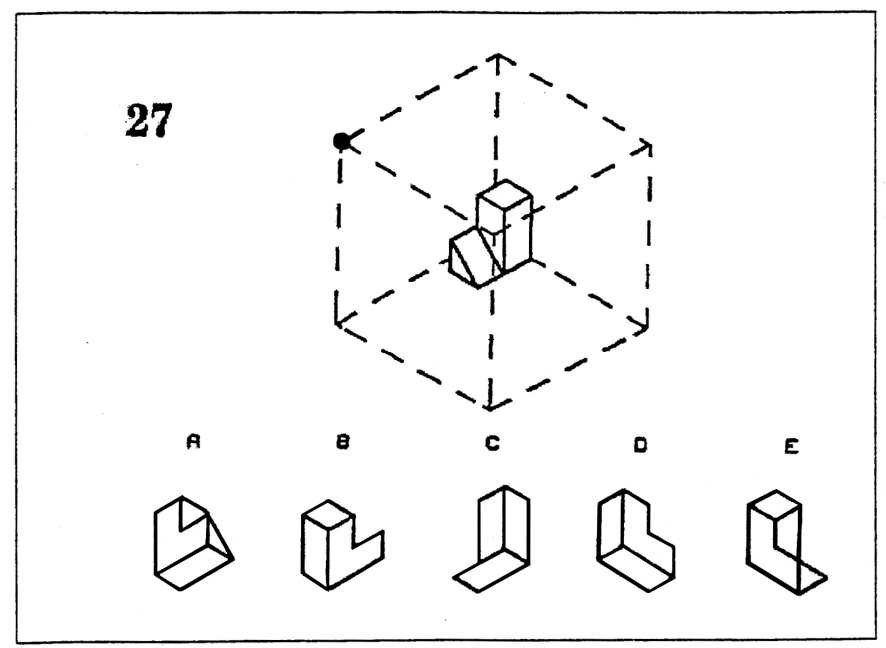

Fig. F.5. PSVT:Views, Item 3

Figure 2. Views Test Example

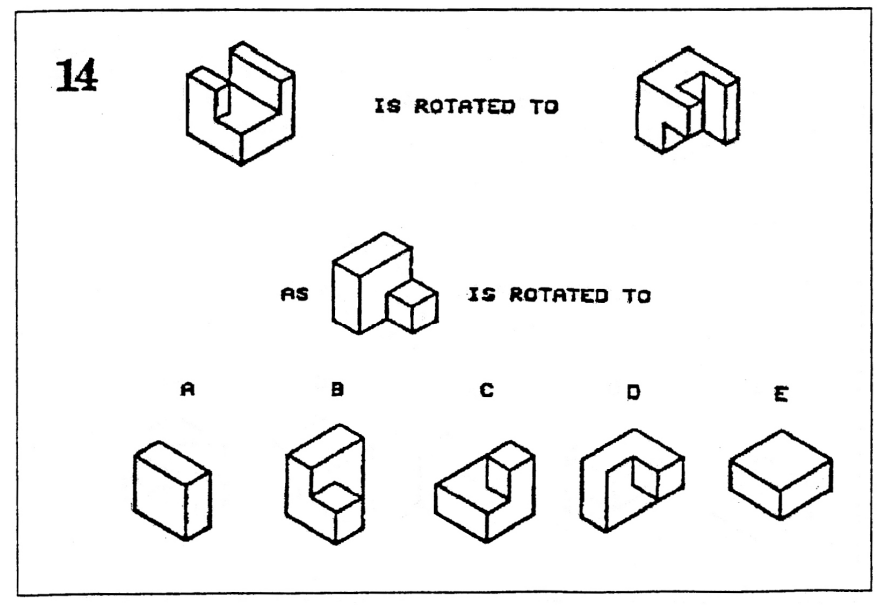

Fig. E.4. PSVT:Rotations, Item 2

Figure 3. Rotation Test Example

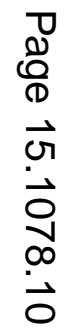

